SAMANTA MITIKO MIZOGUTI

OS DOCUMENTOS PRODUZIDOS EM NEGOCIAÇÕES DE OPERAÇÕES DE FUSÕES E AQUISIÇÕES: NATUREZA JURÍDICA E EFICÁCIA

Dissertação de Mestrado

Orientador: Professor Dr. Rodrigo Octávio Broglia Mendes

UNIVERSIDADE DE SÃO PAULO

FACULDADE DE DIREITO

São Paulo - SP

2017 

SAMANTA MITIKO MIZOGUTI

$N^{\circ}$ USP $887311-0$

\section{OS DOCUMENTOS PRODUZIDOS EM NEGOCIAÇÕES DE OPERAÇÕES DE FUSÕES E AQUISIÇÕES: NATUREZA JURÍDICA E EFICÁCIA}

Dissertação apresentada à Banca Examinadora do Programa de Pós-Graduação em Direito, da Faculdade de Direito da Universidade de São Paulo, como exigência parcial para obtenção do título de Mestre em Direito, na área de concentração de Direito Comercial, sob a orientação do Professor Dr. Rodrigo Octávio Broglia Mendes.

UNIVERSIDADE DE SÃO PAULO

FACULDADE DE DIREITO

São Paulo - SP 
MIZOGUTI, SAMANTA MITIKO.

Os documentos produzidos em negociações de operações de fusões e aquisições: natureza jurídica e eficácia / Samanta Mitiko Mizoguti. Orientador: Professor Dr. Rodrigo Octávio Broglia Mendes. São Paulo: Faculdade de Direito da Universidade de São Paulo, 2017.

$238 \mathrm{p}$.

Dissertação apresentada à Banca Examinadora do Programa de PósGraduação em Direito, da Faculdade de Direito da Universidade de São Paulo, como exigência parcial para obtenção do título de Mestre em Direito, na área de concentração de Direito Comercial.

1. Negociações

2. Fusões e Aquisições

3. Responsabilidade Civil

4. Contratos 
MIZOGUTI, Samanta Mitiko. Os documentos produzidos em negociações de operações de fusões e aquisições: natureza jurídica e eficácia. Mestrado em Direito. Faculdade de Direito da Universidade de São Paulo, São Paulo, 13 de janeiro de 2017.

Aprovado em:

Banca Examinadora

Prof. Dr.

Julgamento:

Instituição:

Assinatura:

Prof. Dr.

Julgamento:

Instituição:

Assinatura:

Prof. Dr.

Julgamento:

Instituição:

Assinatura: 

Para Antonio Paulo 



\section{AGRADECIMENTOS}

Agradeço ao Professor Rodrigo Octávio Broglia Mendes, pela orientação, convivência e confiança em mim depositada.

Agradeço aos professores, amigos e colegas do mestrado da Faculdade de Direito da Universidade de São Paulo, pelo apoio e conhecimentos compartilhados.

Agradeço aos amigos e colegas do escritório TozziniFreire Advogados, em especial a Fernando Eduardo Serec, por todos os anos de convivência, aprendizado e apoio.

Agradeço aos meus pais e ao meu irmão, pelo apoio incondicional e incentivo aos estudos.

Por fim, um agradecimento especial para Antonio Paulo pelo amor, paciência, apoio, colaboração e compreensão durante a elaboração deste trabalho. 



\section{SUMÁRIO}

RESUMO

ABSTRACT

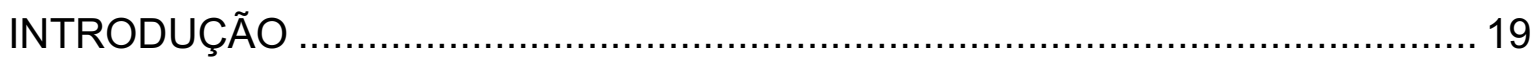

1. O caso concreto que inspirou este trabalho ……….................................. 19

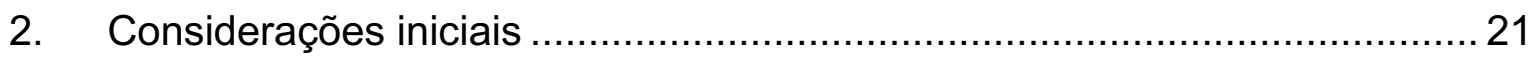

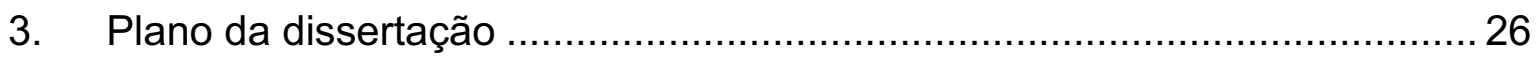

PARTE I OS DOCUMENTOS FIRMADOS EM NEGOCIAÇÕES DE OPERAÇÕES DE FUSÕES E AQUISIÇÕES E O SEU CONTEXTO ………………………..... 29

CAPÍTULO I - AS OPERAÇÕES DE FUSÕES E AQUISIÇÕES ...........................31

1.1. O conceito de operações de fusões e aquisições ....................................... 31

1.2. As principais estruturas jurídicas adotadas em operações de fusões e

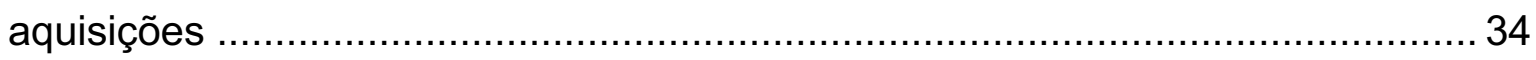

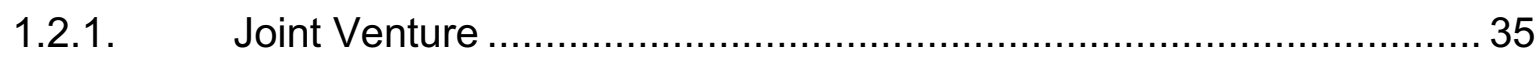

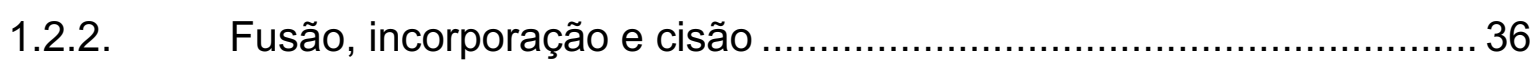

1.2.3. Aquisição (secundária) de participações societárias ......................... 39

1.2.4. Aquisição (primária) de participações societárias - emissão de ações

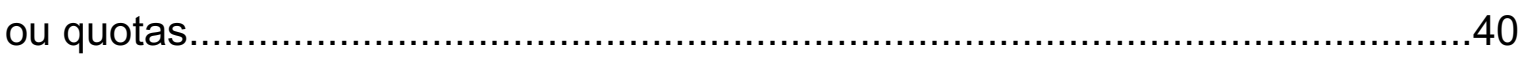

1.2.5. Alienação de ativos ou trespasse de estabelecimento comercial ...... 40

1.3. A complexidade das negociações em operações de fusões e aquisições ... 41

1.3.1. Início das negociações e sua formalização........................................ 44

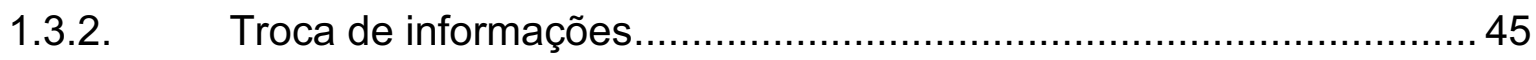

1.3.3. Determinação do preço, do formato do negócio e suas demais

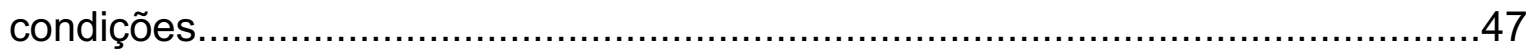

1.3.4. A conclusão do contrato e as condições precedentes ........................ 48

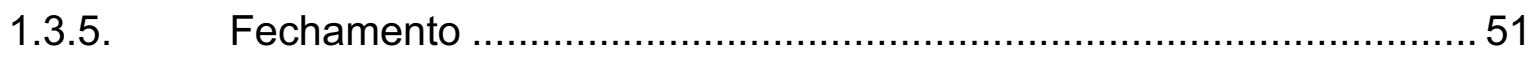

1.4. A complexidade das negociações de operações de fusões e aquisições e os documentos firmados durante o seu curso pelos candidatos a contratante ..........52

CAPÍTULO II - OS DOCUMENTOS FIRMADOS EM NEGOCIAÇÕES DE OPERAÇÕES DE FUSÕES E AQUISIÇÕES ......................................................55

2.1. Os documentos firmados em negociações de operações de fusões e aquisições 55

2.2. A posição da doutrina brasileira a respeito dos documentos firmados durante negociações 59 
CAPÍTULO III - O REGIME JURÍDICO APLICÁVEL ÀS NEGOCIAÇÕES ..........67

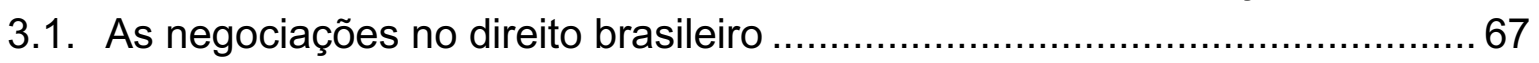

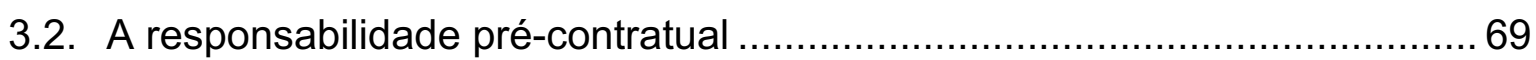

3.2.1. Estudos iniciais relativos à responsabilidade pré-contratual ...............71

3.2.2. As hipóteses de incidência da responsabilidade pré-contratual ........74

3.2.2.1. O princípio do neminem laedere e a responsabilidade pré-contratual76

3.2.2.2. A violação de deveres decorrentes da boa-fé objetiva e a

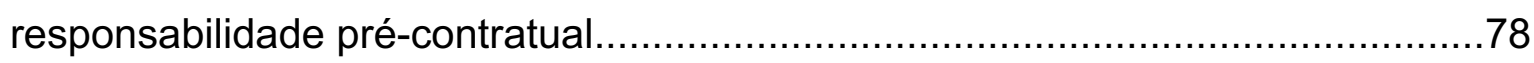

3.2.2.3. O abuso do direito e a responsabilidade pré-contratual...................... 86

3.2.3. A responsabilidade pré-contratual e a reparação de danos................ 89

3.3. Figuras previstas em lei que podem surgir em negociações........................ 95

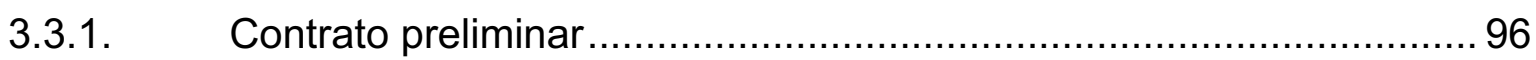

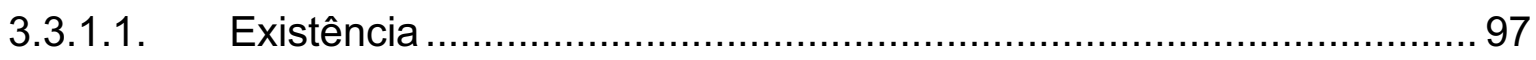

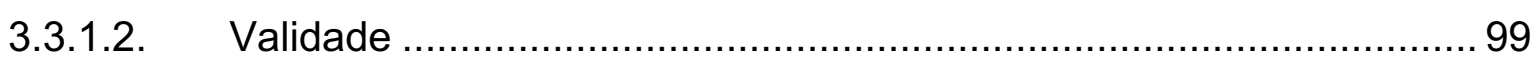

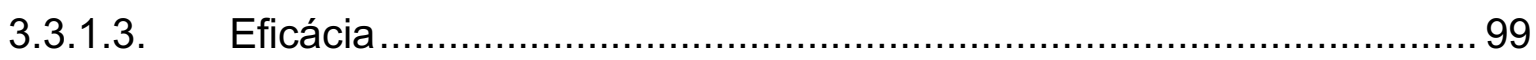

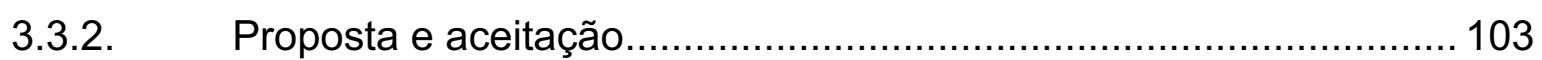

3.4. A importância do princípio da boa-fé objetiva em negociações.................. 105

CAPÍTULO IV - A BOA-FÉ OBJETIVA NAS NEGOCIAÇÕES........................... 109

4.1. A aplicação da boa-fé objetiva nas negociações..................................... 109

4.2. A boa-fé objetiva como norma de criação de deveres pré-contratuais....... 109

4.2.1. Os deveres jurídicos e suas fontes ........................................... 110

4.2.1.1. Os deveres de prestação ........................................................... 111

4.2.1.2. Os deveres anexos ou instrumentais ......................................... 112

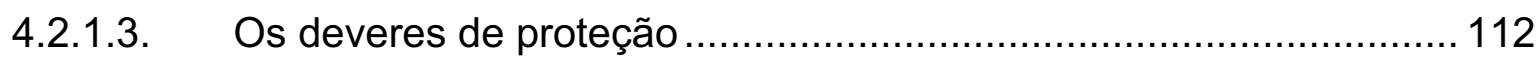

4.2.2. Os deveres jurídicos na fase pré-contratual.................................... 113

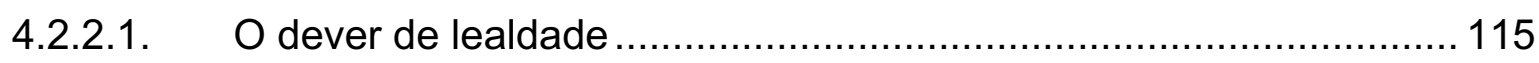

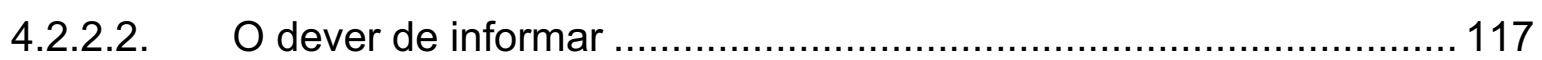

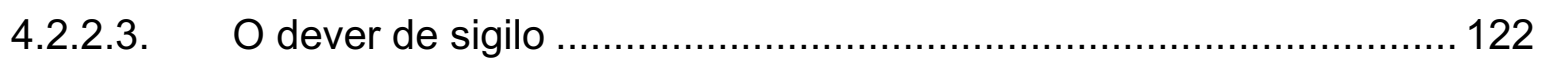

4.2.2.4. O dever de proteção em sentido estrito …………......................... 123

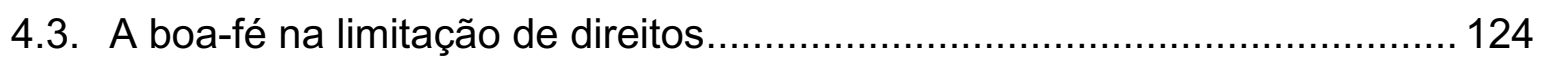

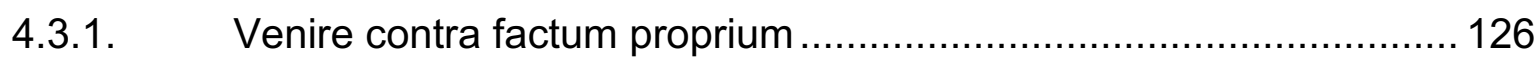

4.3.2. Suppressio e surrectio................................................................... 127

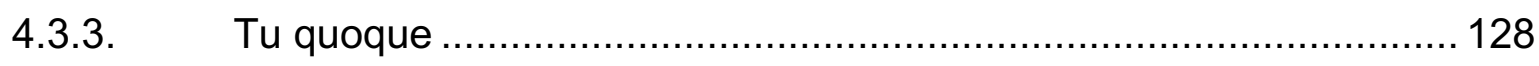

4.3.4. O desequilíbrio no exercício jurídico ............................................. 129

4.4. As incertezas decorrentes da aplicação do princípio da boa-fé nas

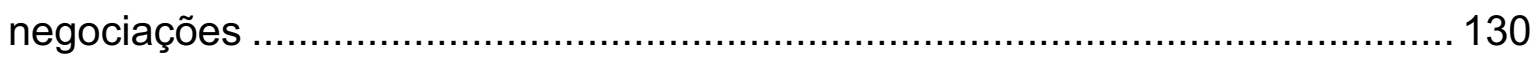


CAPÍTULO V - A NATUREZA JURÍDICA E EFICÁCIA DOS DOCUMENTOS FIRMADOS EM NEGOCIAÇÕES DE OPERAÇÕES DE FUSÕES E AQUISIÇÕES135

5.1. A necessária análise do conteúdo dos documentos firmados em negociações de operações de fusões e aquisições para apuração da natureza jurídica e eficácia 135

5.2. A divisão funcional das cláusulas mais recorrentes em documentos firmados em negociações de operações de fusões e aquisições 137

5.3. Conceitos prévios essenciais ao estudo da natureza jurídica e eficácia das cláusulas mais recorrentes em documentos firmados em negociações de operações de fusões e aquisições 137

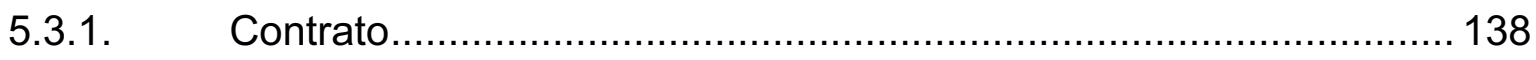

5.3.2. Ato jurídico em sentido estrito .................................................. 139

5.4. A natureza jurídica e eficácia das cláusulas cuja função é disciplinar as

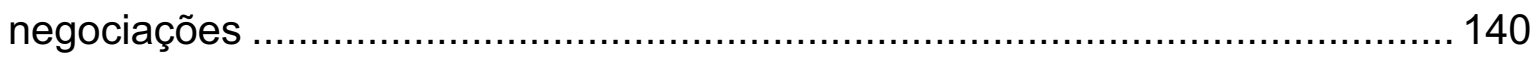

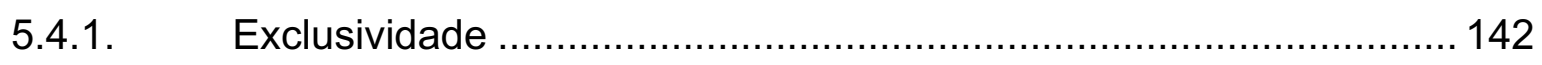

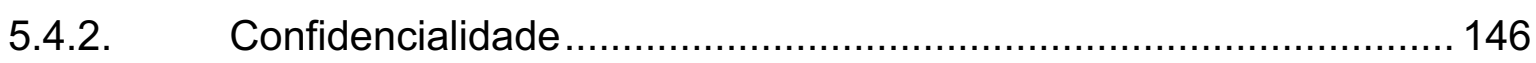

5.4.3. Rateio de despesas decorrentes da negociação ............................. 149

5.4.4. Direito de encerrar as negociações a qualquer momento e por

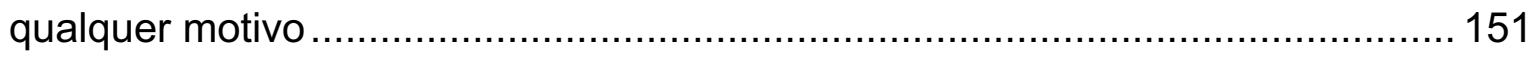

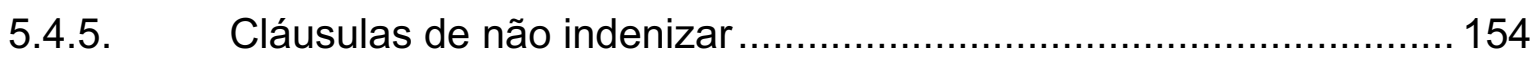

5.4.6. Resolução de disputas ............................................................. 158

5.5. A natureza jurídica e eficácia das cláusulas cuja função é definir aspectos do contrato definitivo

5.6. A natureza jurídica e a eficácia das cláusulas cuja função é auxiliar no gerenciamento das expectativas relacionadas à celebração do contrato definitivo170 5.6.1. Cláusulas estabelecendo a existência ou não de vinculação dos candidatos a contratante aos termos do documento firmado em negociações e à celebração do contrato definitivo................................................................... 170

5.6.2. Obrigação de negociar, envidando esforços para o sucesso da negociação 174

5.6.3. Cláusulas estabelecendo as condições para a celebração do contrato definitivo 176

5.7. Os níveis de proximidade dos candidatos a contratante da obrigação de

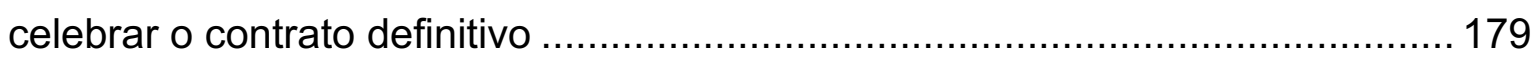

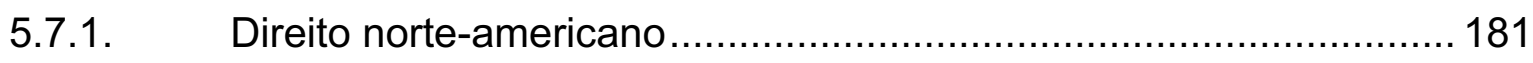

5.7.2. Análise dos níveis de proximidade dos candidatos a contratante com

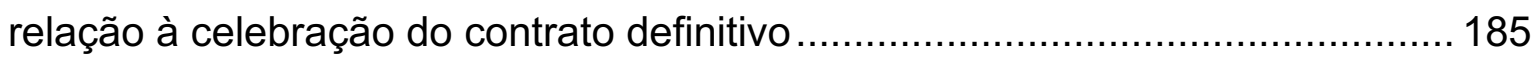

5.7.2.1. Nível 1: há obrigação expressa de celebrar o contrato definitivo e estão presentes os elementos essenciais do contrato definitivo 185 
5.7.2.2. Nível 2: há obrigação expressa de celebrar o contrato definitivo, mas não estão presentes os elementos essenciais do contrato definitivo 190

5.7.2.3. Nível 3: não há obrigação expressa de celebrar o contrato definitivo192 5.8. Conclusão parcial 194

CAPÍTULO VI - OS DOCUMENTOS FIRMADOS EM NEGOCIAÇÕES DE OPERAÇÕES DE FUSÕES E AQUISIÇÕES, O ENCERRAMENTO LITIGIOSO DAS NEGOCIAÇÕES E A RESPONSABILIDADE PELA RUPTURA DAS NEGOCIAÇÕES 199

6.1. A apuração de eventual responsabilidade pela ruptura das negociações e a análise da negociação como um todo 199

6.2. Atos subsequentes à celebração de documentos em negociações 203

6.3. A eficácia das cláusulas previstas nos documentos firmados em negociações de operações de fusões e aquisições diante dos atos subsequentes praticados pelos candidatos a contratante 206

6.3.1. Cláusulas relacionadas à proximidade dos candidatos a contratante

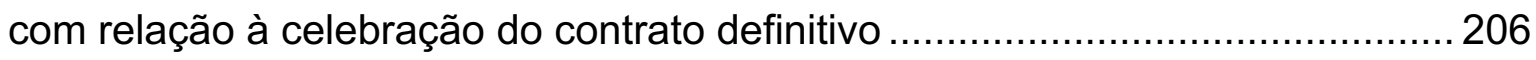

6.3.2. Cláusulas cuja função é disciplinar as negociações .........................213

6.3.2.1. Cláusula prevendo o direito de encerrar as negociações e o rateio de

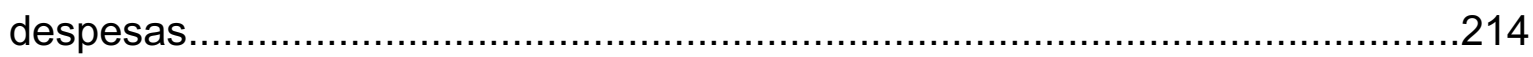

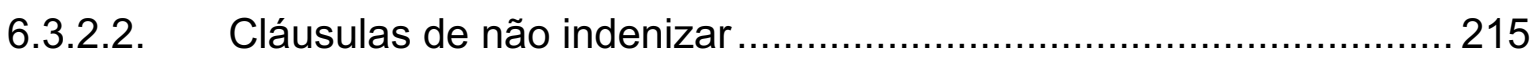

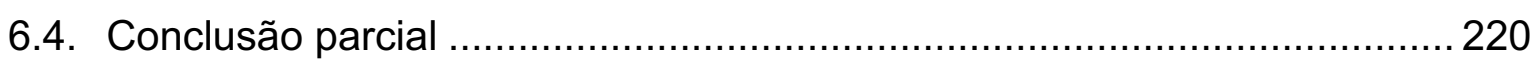

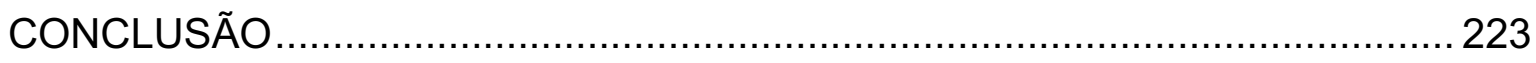

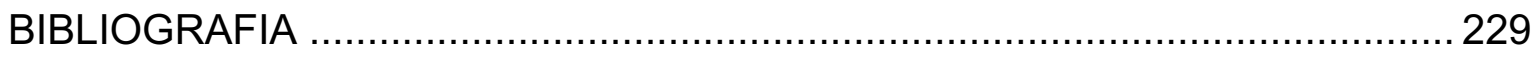




\section{LISTA DE SIGLAS E ABREVIATURAS}

Código Civil ou CC

CPC de 1973

CPC de 2015

Constituição Federal ou CF

CVM

Decreto-Lei $\mathrm{n}^{\circ}$ 2.627/1940

Lei das S.A. ou LSA
Lei Federal $n^{\circ} 10.406$, de 10 de janeiro de 2002, que institui o Código Civil.

Lei Federal $n^{\circ}$ 5.869, de 11 de janeiro de 1973, que institui o Código de Processo Civil.

Lei $n^{\circ} 13.105$, de 16 de março de 2015, que institui o Novo Código de Processo Civil

Constituição da República Federativa do Brasil, de 5 de outubro de 1988

Comissão de Valores Mobiliários.

Decreto-Lei $n^{\circ} 2.627$, de 26 de setembro de 1940, que regulamentava a constituição e o funcionamento das sociedades por ações antes da promulgação da LSA.

Lei Federal $n^{\circ}$ 6.404, de 15 de dezembro de 1976, que regula a constituição e o funcionamento das sociedades por ações.

Novo Código de Lei $n^{\circ} 13.105$, de 16 de março de 2015, que institui o Processo Civil ou Novo Novo Código de Processo Civil CPC

STF

Supremo Tribunal Federal

STJ

Superior Tribunal de Justiça

TJ/RJ

Tribunal de Justiça do Estado do Rio de Janeiro

TJ/RS

Tribunal de Justiça do Estado do Rio Grande do Sul

TJ/SP

Tribunal de Justiça do Estado de São Paulo 



\section{RESUMO}

MIZOGUTI, Samanta Mitiko. Os documentos produzidos em negociações de operações de fusões e aquisições: natureza jurídica e eficácia. 238 páginas. Mestrado em Direito. Faculdade de Direito da Universidade de São Paulo, São Paulo, 13 de janeiro de 2017.

O objetivo desta dissertação é analisar os efeitos jurídicos decorrentes dos documentos produzidos em negociações de operações de fusões e aquisições e o impacto que os demais atos dos candidatos a contratante durante as negociações, subsequentes a eles, tem em seus efeitos jurídicos. Como o conteúdo e o título desses documentos é muito variável na prática, para se extrair os efeitos jurídicos por eles produzidos, analisou-se a natureza jurídica e a eficácia das cláusulas mais recorrentes neles. Tal análise demonstrou que os documentos produzidos em negociações de operações de fusões e aquisições podem gerar obrigações contratuais entre os candidatos a contratante, que trarão maior previsibilidade e segurança com relação à disciplina das negociações e eventual obrigação de celebrar o contrato definitivo ou de negociar, envidando melhores esforços, especialmente diante das incertezas decorrentes da aplicação da boa-fé objetiva na qualidade de princípio e cláusula geral. Além disso, independentemente de sua natureza jurídica, o disposto nos documentos servirá, em última instância, de prova das expectativas geradas entre os candidatos a contratante ao longo das negociações. Como a maioria das cláusulas analisadas tem natureza contratual, aquilo nelas disposto deve, em regra, prevalecer nos casos de encerramento litigioso das negociações. Isso porque, em contratos empresariais prepondera o princípio do pacta sunt servanda. Os atos subsequentes praticados pelos candidatos a contratante durante as negociações somente terão algum impacto nos efeitos jurídicos típicos produzidos pelos documentos em situações específicas analisadas ao longo do trabalho.

Palavras-chave: negociações - operações de fusões e aquisições - boa-fé objetiva - contratos - contrato preliminar - eficácia. 



\section{ABSTRACT}

MIZOGUTI, Samanta Mitiko. Documents executed during negotiations of Merger and Acquisition Transactions: legal nature and efficacy. 238 pages. Master of Laws. Law School, University of São Paulo, January 13th, 2017.

The purpose of this dissertation is to analyze the legal effects resulting from the documents produced in mergers \& acquisition negotiations and the impact that the other acts of the parties during the negotiations, and subsequent to them, have in their legal effects. As the content and title of these documents are very inconstant, in order to extract the legal effects produced by them, the legal nature and the effectiveness of the most usual clauses in them was analyzed. Such analysis demonstrated that documents produced in mergers \& acquisition negotiations may generate contractual obligations between the parties, which will provide greater predictability and security with respect to the regulation of the negotiations and to the obligation to execute the definitive agreement or to negotiate endeavoring best efforts, especially considering the uncertainties arising from the application of objective good faith as principle and general clause. Moreover, irrespective of their legal nature, the provisions in the documents will ultimately serve as evidence of the expectations generated by the parties throughout the negotiations. As most of the clauses hereby analyzed are of a contractual nature, the provisions in them should, as a rule, prevail in disputes regarding the termination of the negotiations. This is because, in business contracts, the principle of pacta sunt servanda prevails. Subsequent acts of the parties will only have an impact on the typical legal effects produced by the documents in specific situations analyzed throughout the work.

Keywords: Negotiations - mergers and acquisitions - objective good faith contracts - preliminary contract - effectiveness. 



\section{INTRODUÇÃO}

\section{O caso concreto que inspirou este trabalho}

O interesse pelo tema deste trabalho foi impulsionado por um caso concreto, que será retratado a seguir para permitir uma melhor compreensão dos problemas dogmáticos que serão aqui enfrentados.

Uma empresa transnacional, aqui denominada "Adquirente $X$ ", líder de mercado em seu ramo e sem penetração no mercado brasileiro, iniciou negociações com uma empresa brasileira, aqui denominada de "Empresa-Alvo A", visando a aquisição de $100 \%$ de suas quotas.

Paralelamente às negociações com a Empresa-Alvo $\mathrm{A}$, a empresa Adquirente $\mathrm{X}$ iniciou negociações com outra empresa brasileira, aqui denominada "Empresa-Alvo B". Apesar de haver uma certa sobreposição entre as suas atividades, as Empresas-Alvo $A$ e $B$ atuavam preponderantemente em ramos complementares, o que, a princípio, viabilizaria a criação de uma plataforma mais abrangente pela empresa Adquirente $\mathrm{X}$ no mercado brasileiro por meio da aquisição de ambas as empresas brasileiras.

Com o objetivo de disciplinar as negociações e resguardar seus interesses, a Adquirente $\mathrm{X}$ e a Empresa-Alvo $\mathrm{A}$ firmaram alguns documentos por elas intitulados term-sheets e cartas de intenção, e negociaram os termos de certas minutas contratuais e alguns outros documentos conforme a formatação do negócio amadurecia e o instrumento do contrato definitivo ganhava corpo.

O documento intitulado term-sheet estabelecia diversas cláusulas que tinham como objetivo limitar riscos e gerenciar as expectativas das partes durante a fase de negociações da operação, a saber: (i) cláusula determinando que as partes não estavam vinculadas à celebração do contrato definitivo; (ii) cláusula prevendo que as partes eram livres para encerrar as negociações a qualquer tempo e por qualquer motivo; (iii) cláusulas indicando que a celebração do contrato definitivo dependia de resultados satisfatórios das auditorias (due diligence), da aprovação da operação pelo conselho de administração da 
Adquirente X; (iv) cláusula determinando que cada parte iria arcar com os seus custos e despesas, se as negociações fossem encerradas, com exceção dos custos relativos à auditoria ambiental, que seriam de responsabilidade da Adquirente $\mathrm{X}$, entre outras cláusulas.

Após aproximadamente um ano de negociações com as Empresas-Alvo A e $B$, a Adquirente $X$ celebrou o contrato de aquisição de quotas da Empresa-Alvo $\mathrm{B}$ e continuou as negociações preliminares com a Empresa-Alvo A.

Decorridos aproximadamente oito meses da aquisição da Empresa-Alvo B, a Adquirente $X$ decidiu encerrar as negociações com a Empresa-Alvo $A$, pois notou uma queda considerável de seu desempenho financeiro nos últimos meses de tal período, informação que obteve após a análise dos documentos entregues a ela pela Empresa-Alvo A em data próxima ao encerramento das negociações. Inconformada, a Empresa-Alvo A ajuizou ação indenizatória contra a Adquirente $X$ visando obter vultosa indenização por danos materiais e pela suposta perda de uma chance decorrente do fato de a Empresa-Alvo $A$ ter se comprometido a negociar em caráter de exclusividade com a Adquirente $X^{1}$.

Os principais argumentos apresentados pela Empresa-Alvo A para justificar a responsabilidade da Adquirente $X$ pela ruptura das negociações foram: (i) a existência de confiança legítima de que o contrato definitivo seria firmado, em razão do estágio avançado em que se encontravam as negociações no momento da ruptura; e (ii) inexistência de motivo que justificasse o encerramento das negociações.

Com relação a esse último argumento, a Empresa-Alvo A sustentou que a sua queda de desempenho teria sido apenas um pretexto utilizado pela Adquirente $X$ para encerrar as negociações, já que a verdadeira razão da ruptura teria sido a sua perda de interesse na aquisição da Empresa-Alvo $A$ tendo em vista a concretização da aquisição da Empresa-Alvo B pela Adquirente $X$.

\footnotetext{
${ }^{1}$ A "perda de uma chance" é caracterizada pela doutrina como a perda da probabilidade de um resultado favorável ou da probabilidade de se evitar uma perda. Sobre a teoria da perda de uma chance conferir: SAVI, Sérgio. Responsabilidade Civil por Perda de uma Chance. São Paulo: Ed. Atlas, 2006; PETEFFI DA SILVA, Rafael. Responsabilidade Civil pela Perda de uma Chance. São Paulo: Ed. Atlas, 2007.
} 
O juiz de primeira instância conclui pela responsabilidade da Adquirente $X$ pela ruptura injustificada das negociações, condenando-a a restituir todas as despesas incorridas pela Empresa-Alvo A com as negociações. Quanto ao pedido de indenização por perda de uma chance, este foi julgado improcedente.

Diversas inquietações surgiram a partir da análise do caso concreto acima relatado:

(i) Afinal, quais são os efeitos jurídicos típicos produzidos pelo termsheet firmado entre a Adquirente $\mathrm{X}$ e a Empresa-Alvo A durante as negociações da operação de fusões e aquisições?

(ii) Quais impactos os atos subsequentes praticados pela Adquirente $X$ (aquisição da Empresa-Alvo $B$ em meio às negociações com a Empresa-Alvo A) têm nos efeitos jurídicos típicos decorrentes do term-sheet?

(iii) O term-sheet tem o condão de limitar os riscos das partes com relação ao encerramento das (muitas vezes custosas) negociações de operações de fusões e aquisições? Qual seria a relevância jurídica do term-sheet em negociações de operações de fusões e aquisições?

\section{Considerações iniciais}

Nos últimos tempos, a etapa das negociações ganhou maior importância em razão da complexidade dos negócios a elas subjacentes, sendo as operações de fusões e aquisições relevantes exemplos de negócios complexos. ${ }^{2}$

A conclusão de operações de fusões e aquisições depende de uma incessante troca de informações entre as partes, da realização de análises contábil, financeira e jurídica, de aprovações junto a terceiros visando viabilizar o

${ }^{2}$ Giovanni Ettore Nanni explica que “(....) é cada vez mais intensa a fase de discussões preparatórias à conclusão do negócio, pois são muito mais duradouras e complexas do que a forma originária que se estava habituado no âmbito jurídico tradicional. (...) Em algumas ocasiões, a formação dos contratos exige pré-acordos sucessivos, com participação de terceiros, como bancos, seguradoras, garantidores, etc. Isto é, celebração do contrato é um processo longo e delicado, que engloba inúmeras tratativas, envolvendo aspectos técnicos e legais, elaboração de minutas, necessitando, conforme o caso, de obtenção de autorizações administrativas que demandam tempo e assistência qualificada" (NANNI, Giovanni Ettore. Direito Civil e Arbitragem. São Paulo: Ed. Atlas, 2014, p. 123). 
negócio (por exemplo, bancos, seguradoras, outros investidores, etc.), da realização de diversas rodadas de discussão para se chegar a um acordo com relação ao formato e contornos do negócio.

Isso porque, no início das negociações de operações de fusões e aquisições, as partes geralmente não têm informações suficientes a respeito da(s) empresa(s)-alvo objeto do negócio, o que as impede de formar o seu real convencimento com relação ao interesse em realizar ou não o negócio e em quais condições.

Percebe-se, assim, que a fase de negociações de operações de fusões e aquisições é muito delicada, pois, a depender das informações recebidas e da forma com que as partes irão lidar com os pleitos umas das outras, os interesses com relação à realização do negócio podem mudar ou diferentes expectativas com relação à sua realização podem ser geradas.

Diante desse cenário de instabilidade dos interesses das partes nas negociações de operações de fusões e aquisições, verifica-se que é essencial que o ordenamento jurídico, de um lado, garanta a liberdade contratual para que elas possam realizar uma escolha legítima e informada com relação à celebração do contrato definitivo; e, de outro lado, tenha regras claras sobre a forma de condução das negociações, garantindo às partes envolvidas proteção suficiente para coibir eventual comportamento oportunista disfuncional, que possa lesar a confiança gerada em cada uma delas. ${ }^{3}$

Atualmente, a resposta do direito brasileiro para essa situação depende, em grande medida, do entendimento formado pelo Poder Judiciário com relação a cada caso concreto.

Isso porque as negociações são atualmente tuteladas por princípios/cláusulas gerais, como a boa-fé objetiva e a vedação ao abuso de direito, que são conceitos abertos e indeterminados e, por consequência,

\footnotetext{
${ }^{3}$ Karl Larenz explica que "uma coexistência pacífica das pessoas sob leis jurídicas que assegurem a cada um o que é seu' só é possivel quando está garantida a confiança indispensável'. Uma desconfiança total e de todos conduz à eliminação total de todos ou ao domínio do mais forte, quer dizer, ao oposto de um estado jurídico" (LARENZ, Karl. Metodologia da ciência do direito. Coimbra: Fundação Calouste Gulbenkian, 2005, pp. 678-679).
} 
dependem de construção doutrinária e de interpretação jurisprudencial, o que leva tempo para se consolidar. ${ }^{4}$

Acrescente-se a isso o fato de serem poucos os dispositivos legais que regulamentam a fase de negociações ${ }^{5}$. Esses dispositivos legais, no geral, são insuficientes para disciplinar negociações complexas como as de operações de fusões e aquisições, pois tratam da fase de formação do contrato, a partir de figuras como a "proposta" ou "oferta", de um lado, e "aceitação", de outro.

As figuras da "proposta" e da "aceitação" não tutelam efetivamente a fase de negociações, pois, na verdade, representam o seu encerramento. É a partir da convergência entre "proposta" e "aceitação" que o contrato definitivo é formado.

Nesse contexto, verifica-se que o regime jurídico atualmente aplicável à fase de negociações gera uma certa insegurança para as partes e imprevisibilidade quanto aos eventuais custos de transação e demais consequências potencialmente decorrentes delas.

Paralelamente a esse cenário de indeterminação do ordenamento jurídico (e talvez como resposta a isso), a prática comercial tem celebrado com maior frequência alguns documentos, que recebem os mais variados títulos. Por exemplo, carta de intenções, term-sheet, memorando de entendimentos, précontrato, contrato preliminar, protocolo de intenções, entre outros.

Não é somente o título desses documentos que é diversificado, mas também o seu conteúdo. Esses documentos podem apresentar diversas cláusulas, sendo que as mais recorrentes em operações de fusões e aquisições aquelas que visam (i) disciplinar as negociações, (ii) auxiliar no gerenciamento de

\footnotetext{
${ }^{4}$ Giovanni Ettore Nanni esclarece que "a vigência do novo Código Civil brasileiro, com a sua estrutura permeada de cláusulas gerais, conceitos abertos, indeterminados, que não regulamentam de modo completo e exaustivo a norma, possuindo caráter genérico e abstrato, tais como a função social do contrato (art. 421), a probidade e boa-fé objetiva (art. 422), o enriquecimento sem causa (art. 884), o ato ilícito (arts. 186 e 927), o abuso do direito (art. 187), a resolução do contrato por onerosidade excessiva (arts. 478 e 480) etc., gera incerteza acerca da extensão desses conceitos, o que, de uma forma ou de outra, reflete na composição dos negócios complexos. O conhecimento do conteúdo dessas cláusulas gerais dependerá da interpretação jurisprudencial, o que levará vários anos para consolidação" (NANNI, Giovanni Ettore. Direito Civil e Arbitragem. São Paulo: Ed. Atlas, 2014, p. 124).

${ }^{5}$ Atualmente a fase pré-contratual é regulamentada pelos artigos 427 a 443 , e 462 e seguintes do Código Civil.
} 
expectativas com relação à celebração do contrato definitivo e (iii) estabelecer o conteúdo do próprio contrato definitivo.

Apesar de serem comumente utilizados na prática comercial, muito se questiona se esses documentos teriam alguma relevância jurídica, especialmente diante do atual regime jurídico aplicável às negociações.

Alguns dizem que os documentos firmados em negociações de operações de fusões e aquisições não teriam qualquer relevância jurídica, pois o propósito de sua celebração seria somente justificar as negociações junto aos órgãos de administração das empresas nelas envolvidas ou permitir a obtenção de financiamentos junto a bancos durante as negociações. Outros, ainda, argumentam que a tutela da fase de negociações pelo princípio da boa-fé objetiva tornaria a celebração desses documentos dispensável.

A doutrina brasileira estudou pouco esses documentos. ${ }^{6}$ Além disso, a escassa doutrina sobre o tema apresenta limitações, em razão da inexistência de um padrão com relação ao título e conteúdo desses documentos como um todo. É consenso na doutrina brasileira o fato de que uma análise mais precisa desses documentos depende do caso concreto.

\footnotetext{
${ }^{6}$ Sobre a dificuldade do tema, Maristela Basso explica que "as novas figuras, emergentes da prática do comércio internacional, inventadas ou reaproveitadas de acordo com as necessidades modernas, incluem as "cartas de intenção", os "acordos de segredo", as "garantias bancárias", os "contratos-promessa de contratar", e são verdadeiros modelos jurídicos, que não foram contemplados no edifício clássico da teoria tradicional da formação dos contratos. Tanto os advogados-negociadores, como os juízes, ou árbitros que eventualmente serão chamados a dirimir as controvérsias que porventura surjam das relações pré-contratuais, não estão suficientemente preparados para avaliar o teor obrigacional desses novos modelos. Ignorá-los não é a melhor opção, pois a prática revela que inúmeros são os instrumentos pré-contratuais, provisórios ou preparatórios, como os citados, que garantem as negociações. Assim sendo, 0 melhor é enfrentá-los, analisá-los e, na medida do possível, determinar seu fundamento, vigência e eficácia" (BASSO, Maristela. Contratos Internacionais do Comércio - Negociação, Conclusão, Prática. $3^{a}$ ed., Porto Alegre: Ed. Livraria do Advogado, 2002, p. 181). Com posição similar, Sílvio de Salvo Venosa comenta que "como forma de repulsa ao contratualismo, surge, no Direito anglosaxão, e hoje se espraia entre nós, a praxe empresarial de não contratar. Originalmente, surge no seio de um grupo de empresas a vontade de não contratar. Preferem elas disciplinar suas relações com base na palavra dada, com uma simples carta de intenções, ou o chamado acordo de cavaleiros (gentlemen's agreement). (...) O teor do acordo de cavalheiros, por outro lado, pode dar valiosos elementos de interpretação ao julgador, para a investigação da vontade das partes, quando ocorrer conflito ou pretensão resistida. Nesse campo acontratual ou pré-contratual realçase a importância do exame da boa-fé objetiva, como apontamos neste capitulo. O fenômeno, sem dúvida, está já a merecer maior atenção do jurista" (VENOSA, Sílvio de Salvo. Direito Civil Teoria Geral das Obrigações e Teoria Geral dos Contratos. $8^{a}$ ed., São Paulo: Ed. Atlas, 2008, p. 359).
} 
Não obstante, a doutrina brasileira apresenta algumas importantes conclusões a respeito desses documentos. Além de apontar a possibilidade de serem verdadeiros contratos, a doutrina majoritária classifica esses documentos em duas principais categorias: contrato preliminar e "cartas de intenções"

Seriam contratos preliminares aqueles documentos em que as partes se obrigam a celebrar o contrato definitivo, mesmo nas situações em que ainda não tenham chegado a um acordo sobre todos os seus aspectos. O principal efeito dos contratos preliminares seria a vinculação das partes à celebração do contrato definitivo.

Já os documentos em que as partes não se obrigam a celebrar o contrato definitivo seriam classificados, genericamente, como "cartas de intenção". As cartas de intenção são entendidas pela doutrina como (i) atos jurídicos em sentido estrito, cujos efeitos decorrem da lei, mais especificamente do princípio da boa-fé objetiva; ;ii) uma forma de contato social gerador de relação jurídica obrigacional entre as partes, na qual incide o princípio da boa-fé objetiva, especialmente na sua função criadora de deveres"; ou (iii) um instrumento para que as partes possam "espessar" os deveres decorrentes do princípio da boa-fé objetiva ${ }^{10}$.

Apesar de a doutrina brasileira adotar caminhos diferentes para explicar o fenômeno das cartas de intenção, o fato é que, independentemente do caminho adotado, a conclusão é praticamente a mesma: as cartas de intenção devem ser interpretadas pela aplicação do princípio da boa-fé objetiva.

Tais conclusões apresentadas pela doutrina são insuficientes para responder às questões indicadas acima com relação ao caso concreto inspirador deste trabalho. Afinal, não há um entendimento acerca dos efeitos específicos decorrentes desses documentos, considerando todas as cláusulas que neles

\footnotetext{
7 A nomenclatura "carta de intenções" é adotada por grande parte da doutrina para fazer referência aos documentos firmados durante as negociações em que não há obrigação de as partes celebrarem o contrato definitivo.

${ }^{8}$ Nesse sentido: (i) JUNQUEIRA DE AZEVEDO, Antonio. Negócio jurídico e Declaração Negocial: Noções Gerais e Formação da Declaração Negocial. São Paulo, 1986, p. 42; (ii) LEÃES, Luiz Gastão Paes de Barros. Protocolo de intenções sem força obrigatória. In: Pareceres. Volume I, São Paulo: Ed. Singular, 2004, pp. 404 e 410.

9 MARTINS-COSTA, Judith. As cartas de intenção no processo formativo da contratação internacional: os graus de eficácia dos contratos e a responsabilidade pré-negocial. Trabalho apresentado no seminário sobre "Contratos Internacionais e o MERCOSUL", Faculdade de Direito, Universidade Federal do Rio Grande do Sul, p. 8.

${ }^{10}$ BAPTISTA, Luiz Olavo. Contratos Internacionais. São Paulo: Ed. Lex Magister, 2010, p. 158.
} 
costumam aparecer, em especial nos casos de encerramento litigioso das negociações. Tampouco existe um entendimento sobre a relevância jurídica desses documentos em negociações longas e complexas de operações de fusões e aquisições.

Acrescente-se, ainda, que não há uma indicação precisa de quais seriam os efeitos concretos decorrentes das chamadas "cartas de intenção" diante de seu variado conteúdo e da incidência do princípio da boa-fé objetiva.

A bem da verdade, a posição atual da doutrina parece apenas reforçar que o papel desempenhado por esses documentos nas negociações não é claro, pois o princípio da boa-fé objetiva é a elas aplicável, independentemente das partes celebrarem esses documentos durante o seu curso.

Nesse contexto, partindo-se do regime jurídico atualmente aplicável às negociações de operações de fusões e aquisições e das cláusulas mais recorrentes em tais documentos, o presente trabalho buscará compreender melhor a relevância jurídica da celebração desses documentos em negociações de operações de fusões e aquisições, respondendo às seguintes questões dogmáticas:

(i) Quais são os efeitos jurídicos típicos produzidos pelos documentos firmados em negociações de operações de fusões e aquisições?

(ii) Qual é o impacto que os atos subsequentes à celebração de tais documentos têm nos efeitos jurídicos típicos por eles produzidos, especialmente nos casos de ruptura das negociações? Esses documentos têm o condão de limitar os riscos decorrentes do encerramento das negociações de operações de fusões e aquisições?

\section{Plano da dissertação}

A dissertação está dividida em 3 partes.

O objeto de análise da primeira parte deste trabalho são os documentos firmados em negociações de operações de fusões e aquisições, bem como as circunstâncias em que eles são celebrados. 
Para compreender as circunstâncias em que são firmados os documentos em negociações de operações de fusões e aquisições, estudaremos, inicialmente, as principais operações de fusões e aquisições e as etapas mais comuns das negociações dessas operações.

Em seguida, analisaremos os contornos dos documentos firmados em negociações de operações de fusões e aquisições, bem como a posição atual da doutrina brasileira a respeito dos documentos firmados em negociações de uma forma geral.

Na segunda parte deste trabalho, o objetivo é compreender o regime jurídico atualmente aplicável às negociações de uma forma geral, obtendo, assim, a base para se extrair o quanto os documentos firmados em negociações de operações de fusões e aquisições contribuem na tutela do interesse das partes nas negociações a partir de seus efeitos jurídicos.

Em um primeiro momento, estudaremos as linhas gerais da responsabilidade pré-contratual. Existem ainda algumas controvérsias na doutrina brasileira a respeito de determinados aspectos da responsabilidade précontratual. Por exemplo, a natureza da responsabilidade pré-contratual (contratual, extracontratual ou sui generis). Como o objetivo deste estudo não é enfrentar tais controvérsias, a responsabilidade pré-contratual será analisada de forma breve.

Em seguida, analisaremos o princípio da boa-fé objetiva em suas funções de criação de deveres e de limitação do exercício de direitos. Isso porque o princípio da boa-fé é, em última instância, o principal fundamento da tutela na fase de negociações no ordenamento jurídico pátrio.

Por fim, estudaremos duas figuras disciplinadas pelo Código Civil, que aparecem com certa frequência em negociações: (i) o contrato preliminar; e (ii) proposta e aceitação. O estudo dessas figuras contribuirá para a melhor compreensão dos documentos firmados em negociações de operações de fusões e aquisições, em especial, o contrato preliminar.

$\mathrm{Na}$ terceira e última parte desta dissertação, o objetivo é analisar os efeitos jurídicos típicos produzidos pelos documentos firmados em negociações de 
operações de fusões e aquisições, bem como o reflexo do encerramento litigioso das negociações nos efeitos jurídicos típicos desses documentos.

Considerando-se que os efeitos jurídicos produzidos pelos documentos firmados em negociações de operações de fusões e aquisições somente podem ser apurados precisamente a partir da análise de seu conteúdo, estudaremos, inicialmente, as cláusulas mais recorrentes nesses documentos e a sua natureza jurídica. A partir da natureza jurídica dessas cláusulas, verificaremos os efeitos jurídicos típicos delas decorrentes.

Em seguida, analisaremos o impacto que o encerramento litigioso das negociações pode ocasionar nos efeitos jurídicos típicos decorrentes das cláusulas previstas nos documentos firmados em negociações de operações de fusões e aquisições, que visam limitar riscos e gerenciar expectativas. Para auxiliar nessa análise, estudaremos, de forma breve, a jurisprudência envolvendo os documentos firmados em negociações e a responsabilidade pela ruptura de tais negociações.

Finalmente, analisaremos criticamente os efeitos jurídicos produzidos pelos documentos firmados em negociações de operações de fusões e aquisições à luz do regime jurídico aplicável às negociações, para, assim, apurar o quanto esses documentos efetivamente contribuem na limitação de riscos relacionados ao encerramento litigioso das negociações, bem como o seu papel nas complexas negociações de operações de fusões e aquisições. 


\section{CONCLUSÃO}

As negociações de operações de fusões e aquisições são geralmente longas, complexas e desempenham um papel de grande relevância para a concretização do negócio. É por meio das negociações que os candidatos a contratante tomam conhecimento das informações necessárias para estabelecer o formato do negócio, suas condições e, até mesmo, o seu efetivo interesse em realizá-lo.

Antes da conclusão de uma operação de fusão e aquisição muitas informações são trocadas, diversas rodadas de discussão e análises são realizadas por assessores dos candidatos a contratante.

Diante da necessidade de tantas informações, análises e discussões, é comum que os candidatos a contratante alterem suas posições e interesses ao longo das negociações, concluindo, inclusive, pela sua falta de interesse em realizar o negócio.

Atualmente, o ordenamento jurídico pátrio não apresenta dispositivos específicos para regulamentar negociações complexas como as de operações de fusões e aquisições. Os dispositivos previstos no Código Civil tratam basicamente das figuras da proposta e da aceitação, que representam, no geral, a conclusão do contrato, ou seja, a fase final das negociações.

A partir da prática comercial, verifica-se que, em meio a esse cenário de incertezas em relação ao potencial negócio, possíveis mudanças de interesses ao longo das negociações e ausência de regulamentação específica pelo ordenamento jurídico pátrio, é comum que os candidatos a contratante produzam documentos durante as negociações de operações de fusões e aquisições. Esses documentos podem apresentar os mais variados títulos e conteúdos, inexistindo um padrão com relação a eles.

Devido à ausência de um padrão com relação a esses documentos, a doutrina brasileira, apesar de apresentar importantes lições sobre eles, indica que uma análise mais precisa dependeria do estudo do caso concreto.

Em razão disso, para ter uma compreensão mais precisa sobre os efeitos jurídicos produzidos pelos documentos firmados em negociações de operações 
de fusões e aquisições, foram analisadas as cláusulas mais recorrentes nesses documentos.

Verificou-se que essas cláusulas apresentam três principais funções, a saber: (i) disciplinar as negociações; (ii) estabelecer os pontos consensuais do contrato definitivo; e (iii) auxiliar no gerenciamento de expectativas quanto à celebração do contrato definitivo.

As cláusulas visando disciplinar as negociações (tais como as de confidencialidade, exclusividade, entre outras) têm, via de regra, natureza contratual. Assim, o efeito jurídico delas decorrente é a criação de um vínculo contratual entre os candidatos a contratante, permitindo a alocação de riscos entre estes e a previsibilidade quanto ao regramento aplicável às negociações.

As cláusulas estabelecendo os pontos consensuais, por sua vez, podem ter (i) natureza contratual, se inseridas em um documento com características de contrato preliminar, sendo o efeito jurídico típico delas decorrente a vinculação dos candidatos a contratante à celebração do contrato definitivo, observados os seus termos, ou (ii) natureza de declaração, cujos efeitos jurídicos decorrem da lei, mais especificamente do princípio da boa-fé objetiva.

As cláusulas visando auxiliar no gerenciamento de expectativas quanto à celebração do contrato definitivo podem ter natureza contratual, de ônus ou de condição (suspensiva ou resolutiva) como elemento acidental do negócio jurídico. Se forem contratos (por exemplo, a cláusula que prevê a obrigação de celebrar ou de não celebrar - o contrato definitivo), o efeito jurídico delas decorrentes é vincular contratualmente os candidatos a contratante aos seus termos. Se elas forem entendidas como mero ônus, o seu cumprimento irá resultar em uma vantagem para os candidatos a contratante. Se forem condições, o efeito jurídico de sua implementação será o de (i) impor aos candidatos a contratante a obrigação de celebrar o contrato definitivo, se a condição for suspensiva e (ii) encerrar a vigência do contrato preliminar, se a condição for resolutiva.

As cláusulas visando auxiliar no gerenciamento de expectativas quanto à celebração do contrato definitivo e estabelecer os pontos consensuais do contrato definitivo, conjuntamente, permitem a apuração da proximidade dos candidatos a contratante com relação à celebração do contrato definitivo. 
Conforme mencionado no capítulo $\mathrm{V}$, a depender do nível de proximidade dos candidatos a contratante com relação à celebração do contrato definitivo, os documentos produzidos em negociações podem (i) gerar obrigação de celebrar o contrato definitivo; (ii) gerar obrigação de negociar o contrato definitivo, envidando os melhores esforços para o sucesso das negociações; e (iii) indicar somente a intenção dos candidatos a contratante de negociar, inexistindo qualquer obrigação de celebrar o contrato definitivo ou compromisso de envidar melhores esforços para o sucesso das negociações.

Apesar de essas cláusulas produzirem os efeitos jurídicos acima indicados, o fato é que todas elas, indiretamente, permitem a apuração das expectativas legítimas dos candidatos à contratante com relação ao contrato definitivo e às negociações, servindo de elemento de interpretação no caso de encerramento litigioso das negociações.

Partindo-se dos efeitos jurídicos decorrentes dos documentos firmados em negociações de operações de fusões e aquisições, verifica-se, a princípio, que eles (i) vinculam os candidatos a contratante a uma regulamentação das negociações, dando maior previsibilidade e segurança; e, ainda, (ii) são provas concretas das expectativas geradas entre eles desde o início da negociação.

Ou seja, os documentos firmados em negociações de operações de fusões e aquisições, de certa forma, diminuem as incertezas decorrentes da aplicação do princípio da boa-fé objetiva, pois podem criar obrigações contratuais entre os candidatos a contratante e, ainda, servem de prova das expectativas entre eles geradas.

Ocorre, no entanto, que nem sempre as cláusulas previstas nos documentos firmados em negociações de operações de fusões e aquisições produzirão seus efeitos jurídicos típicos no caso concreto.

Conforme analisado no capítulo VI, no caso de encerramento litigioso das negociações, os atos praticados pelos candidatos a contratante, subsequentes à celebração dos documentos em negociações de operações de fusões e aquisições, poderão impactar os efeitos jurídicos típicos por eles produzidos.

Nos casos de encerramento litigioso das negociações, geralmente, duas questões são analisadas: (i) a existência de eventual obrigação entre os 
candidatos a contratante de celebrar o contrato definitivo; e/ou (ii) eventual responsabilidade pré-contratual dos candidatos a contratante.

$\mathrm{Na}$ análise dessas duas questões, serão levados em consideração todos os atos praticados pelos candidatos a contratante ao longo das negociações, sendo os documentos firmados durante o seu curso apenas um elemento dessa análise (naturalmente, tais documentos terão grande relevância nessa análise).

Para averiguar a existência de responsabilidade pré-contratual, será necessário apurar se houve ou não violação da boa-fé objetiva. Apesar de existirem institutos para auxiliar na apuração de eventual violação à boa-fé objetiva (por exemplo, deveres de proteção e figuras como venire contra factum proprium, supressio, surrectio, etc.), o fato é que a aplicação de tais institutos dependerá da análise conjunta de todos os atos praticados pelos candidatos a contratante, que possam ter gerado expectativas legítimas ou alterado o que havia sido acordado entre os candidatos a contratante.

Com relação à apuração da existência de obrigação de celebrar o contrato definitivo, todos os atos praticados pelos candidatos a contratante, que possam ter gerado expectativas legítimas entre eles, também devem ser analisados.

Em regra, o disposto nos documentos firmados em negociações de operações de fusões e aquisições deve prevalecer na análise de eventual obrigação entre os candidatos a contratante de celebrar o contrato definitivo e de eventual responsabilidade pré-contratual dos candidatos a contratante.

Isso porque, na seara do direito comercial, é de grande importância que os pactos sejam respeitados para a manutenção do giro mercantil, sendo tais pactos no presente caso os documentos firmados em negociações de operações de fusões e aquisições.

No geral, há paridade entre os candidatos a contratante de operações de fusões e aquisições. Assim, o que foi por eles acordado em documentos firmados durante as negociações deve ser respeitado, prevalecendo o princípio do pacta sunt servanda.

Tais documentos devem ser entendidos como fortes provas da intenção dos candidatos a contratante, servindo, inclusive, de base para a análise e interpretação dos atos posteriores praticados por eles. 
Somente em situações excepcionais os atos subsequentes praticados pelos candidatos a contratante poderão afastar o disposto nos documentos firmados em negociações de operações de fusões e aquisições. Analisamos alguns exemplos dessas situações no item 6.4 desta dissertação.

Diante desse cenário, verifica-se que os documentos produzidos pelos candidatos a contratante são de grande utilidade em negociações de operações de fusões e aquisições, pois conferem maior previsibilidade e segurança às negociações ao criar obrigações contratuais entre os candidatos a contratante, permitem uma melhor delimitação de riscos decorrentes do encerramento das negociações e são provas das expectativas geradas entre os candidatos a contratante.

No entanto, para que o disposto nos documentos firmados em negociações de operações de fusões e aquisições produzam plenamente os efeitos originalmente pretendidos, é necessário que os candidatos a contratante atentem para os atos subsequentes à celebração daqueles. Em outras palavras, o comportamento dos candidatos a contratante durante as negociações deve ser coerente com o que foi acordado nos documentos firmado em negociações. 



\section{BIBLIOGRAFIA}

ALMEIDA COSTA, Mário Júlio. Responsabilidade Civil pela Ruptura das Negociações Preparatórias de um Contrato. Coimbra: Coimbra, 1984.

ALEM, Fabio Pedro. Contrato preliminar: eficácia nos negócios jurídicos complexos. Mestrado em Direito das Relações Sociais, subárea Direito Civil Comparado, pela Pontifícia Universidade Católica de São Paulo, 2009.

ANTUNES, José Augusto Quelhas Lima Engracia. Contratos Comerciais: Noções Fundamentais. Coimbra: Universidade Católica Editora, 2007.

. "A 'Consuetudo Mercatorum' como Fonte do Direito Comercial". In: Revista de Direito Mercantil, Industrial, Econômico e Financeiro, Volume 146, abril/junho de 2007: Ed. Malheiros, 2007.

BANDEIRA, Luiz Octávio Villela de Viana. As cláusulas de não indenizar no direito brasileiro. São Paulo: Ed. Almedina, 2016.

BAPTISTA, Luiz Olavo. Contratos Internacionais. São Paulo: Ed. Lex Magister, 2010.

. Dos Contratos Internacionais - uma visão teórica e prática. São Paulo: Ed. Saraiva, 1994.

BASSO, Maristela. Contratos Internacionais do Comércio - Negociação, Conclusão, Prática. $3^{a}$ ed., Porto Alegre: Ed. Livraria do Advogado, 2002. . Joint ventures: manual prático das associações empresariais. Porto Alegre: Livraria do Advogado, 1998.

BESSONE, Darcy. Do Contrato: Teoria Geral. 4ª . ed., São Paulo: Saraiva, 1997. BETTI, Emilio. Interpretazione della Legge e degli Atti Giuridici. $2^{\mathrm{a}}$ ed., Milano: Giuffré, 1971.

- Teoria General Del Negocio Jurídico. Tradução de A. Martín Pérez. Granada: Ed. Comares, 2000.

BITTAR, Carlos Alberto. Curso de direito civil. Volume I. Rio de Janeiro: Ed. Forense Universitária, 1991.

BITELLI, Marcos Alberto Sant'Anna. "O Acordo de Não Divulgação (NDA) e a Questão do Rompimento das Negociações". In: Revista de Direito Privado, Volume 51/2012, julho/2012, São Paulo, 2012. 
BLOK, Marcella. Reorganizações Societárias, Fusões, Incorporações, Cisões e outros Eventos Societários: Aspectos Legais, Negociais e Práticos. São Paulo: Quartier Latin, 2014.

BOTREL, Sérgio. Fusões \& Aquisições. São Paulo: Ed. Saraiva, 2012.

; BARBOSA, Henrique. Finanças Corporativas: aspectos jurídicos e estratégicos. São Paulo: Atlas, 2016.

BRODSKY, Stephen. "Federal Courts in New York provide framework for enforcing preliminary agreements". New York State Bar Association Journal, March/April 2001.

BURGARELLI, Waldírio. Fusões, Incorporações e Cisões de Sociedades. $2^{\mathrm{a}}$ ed., São Paulo: Atlas, 1996.

CAPELLARI, Récio Eduardo. Responsabilidade pré-contratual, aplicabilidade ao direito brasileiro. Porto Alegre: Livraria do Advogado, 1995.

CARVALHOSA, Modesto. Comentários à Lei de Sociedades Anônimas, Volume IV, Tomo I. $3^{\text {a }}$ ed., São Paulo: Saraiva, 2002.

CASTRO, Rodrigo Rocha Monteiro de Castro. Regime jurídico das reorganizações: societária, empresarial e associativa. São Paulo: Saraiva, 2016.

CAVALIEIRI FILHO, Sérgio. Programa de responsabilidade civil. $6^{a}$ edição, $2^{a}$ tiragem, São Paulo: Ed. Malheiros, 2006.

CHAVES, Antonio. Responsabilidade pré-contratual. $2^{a}$ ed., São Paulo: Lejus, 1997.

CICERO, Marcus Tullius. De officiis. Tradução para o inglês de Walter Miller. Cambridge: Harvard University Press, 1913. Disponível em: http://www.constitution.org/rom/de officiis.htm\#book3. Acessado em 28.04.2016.

COELHO, Fábio Ulhoa. Curso de Direito Comercial - Volume III. São Paulo: Ed. Saraiva, 2010.

COMPARATO, Fábio Konder. Novos Ensaios e Pareceres de Direito Empresarial. Rio de Janeiro: Ed. Forense, 1981.

CORDEIRO, António Manuel da Rocha e Menezes. Da boa-fé no direito civil. $6^{a}$ reimpressão. Coimbra: Ed. Almedina, 2015. 
COSTA, Judith Martins. "Os Avatares do Abuso do Direito e o Rumo Indicado pela Boa-Fé". In: TEPEDINO, Gustavo (coord.). Direito Civil Contemporâneo, Coord. São Paulo: Atlas, 2008.

COUTO E SILVA, Clóvis V. Obrigação como Processo. Rio de Janeiro: FGV, 2007.

DAWSON, John P.; HARVEY, William Burnett; HENDERSON, Stanley D.; BAIRD, Douglas G. Contracts: cases and comment. 9th edition, New York: Foundation Press, 2008, p. 383.

DINIZ, Maria Helena. Curso de Direito Civil - 3. Teoria das Obrigações Contratuais e Extracontratuais. São Paulo: Saraiva, 2007.

. Curso de direito civil brasileiro. Volume $3,17^{\mathrm{a}}$ ed., São Paulo: Ed. Saraiva, 2002.

DONNINI, Rogério. Responsabilidade civil pós-contratual: no direito civil, no direito do consumidor, no direito do trabalho, no direito ambiental e no direito administrativo. $3^{a}$ edição. São Paulo: Ed. Saraiva, 2011.

FARNSWORTH, E. Allan. Contracts. Boston: Little, Brown and Co., 1990.

; YOUNG, William F. Contracts: cases and materials. $5^{\mathrm{a}}$ ed., Wesbury, New York: The Foundation Press, 1995.

FERNANDES, Wanderley. Cláusulas de Exoneração e de Limitação de Responsabilidade. São Paulo: Ed. Saraiva, 2013.

. (coord.) Fundamentos e Princípios dos Contratos Empresariais. $2^{\mathrm{a}}$ ed., São Paulo: Saraiva, 2012.

. "O Processo de Formação do Contrato". In: FERNANDES, Wanderley (coord.). Fundamentos e Princípios dos Contratos Empresariais. $2^{\mathrm{a}}$ ed., São Paulo: Saraiva, 2012.

; OLIVEIRA, Jonathan Mendes. Contrato Preliminar: Segurança de Contratar. In: FERNANDES, Wanderley (coord.). Fundamentos e Princípios dos Contratos Empresariais. $2^{a}$ ed., São Paulo: Saraiva, 2012.

FOREMAN, Violeta Solonova. Non-binding preliminary agreements: the duty to negotiate in good faith and the award of expectation damages. Volume 72 , University of Toronto Faculty of Law Review, 12/2014.

FRADA, Manuel A. Carneiro. Teoria da Confiança e Responsabilidade Civil. Coimbra: Almedina, 2003. 
FRIED, Charles. Contract as Promise: a Theory of Contractual Obligation. Cambridge, Mass: Harvard University Press, 1981.

FRITZ, Karina Nunes. "A responsabilidade pré-contratual por ruptura injustificada das negociações". In: Revista dos Tribunais, volume 883, maio/2009.

FORGIONI, Paula A. Teoria Geral dos Contratos Empresariais. $2^{\text {a }}$ ed., São Paulo: Revista dos Tribunais, 2011.

GAGLIARDI, Rafael Villar. "Contratos Preliminares". In: LOTUFO, Renan; NANNI, Giovanni Ettore. Teoria Geral dos Contratos, Coord. São Paulo: Atlas, 2011.

GALGANO, Francesco. II Negozio Giuridico. $2^{\text {a }}$ ed., Milano: Giuffrè, 2002.

GARCIA, Ricardo Lupion. Boa-fé Objetiva nos Contratos Empresariais: Contornos Dogmáticos dos Deveres de Conduta. Porto Alegre: Livraria do Advogado, 2011.

GAUGHAN, Patrick A. Mergers, acquisitions and corporate restructuring. New Jersey: John Wiley \& Sons, 2011.

GOGLIANO, Daisy. As Tratativas Contratuais (bases de uma teoria). São Paulo: Quartier Latin do Brasil, 2013.

GOMES, Orlando. Contratos. $26^{\text {a }}$ ed., Rio de Janeiro: Forense, 2007. . Obrigações. $11^{\mathrm{a}}$ ed., Rio de Janeiro: Ed. Forense, 1997.

GRAU, Eros. "Nota sobre a distinção entre obrigação, dever e ônus". Revista USP, 1982, pp. 180-181.

GRAVA, J. William. "Fusões e aquisições: motivadores econômicos e estratégicos". In: SADDI, Jairo (org.). Fusões e aquisições: aspectos jurídicos e econômicos, São Paulo: IOB, 2002.

GRÜN, Mary. A Eficácia dos Documentos Pré-Contratuais. Dissertação de Mestrado - Faculdade de Direito da Universidade de São Paulo, 2006.

GUERREIRO, José Alexandre Tavares. "A Boa-Fé nas Negociações Preliminares". In: Doutrinas Essenciais Obrigações e Contratos, Volume 4, junho/2011, São Paulo, 2011.

. "A boa-fé nas negociações preliminares". In: Revista de Direito Civil, abril/1981.

HUNT, Peter A. Structuring Mergers \& Acquisitions: a guide to creating shareholder value. $2^{\text {nd }}$ ed., Aspen Publishers Inc., 2004.

JUNQUEIRA DE AZEVEDO, Antonio. "A boa-fé na formação dos contratos". In: Revista de Direito do Consumidor, n. 3. São Paulo: Ed. RT, 1992, pp. 79-80. 
Negócio Jurídico - Existência, Validade e Eficácia. 4ª ed., São Paulo: Ed. Saraiva, 2010.

. Negócio Jurídico e Declaração Negocial: Noções Gerais e Formação da Declaração Negocial. São Paulo, 1986.

. Novos estudos e pareceres de direito privado. $2^{\mathrm{a}}$ tiragem, São Paulo: Ed. Saraiva, 2010.

. "Responsabilidade civil - assalto em estacionamento de supermercado estacionamento gratuito como caso de 'relação contratual de fato' - admissão da prova de não-culpa - estupro atentado fora do estacionamento, seguido de morte - falta de relação de causalidade adequada". In: Revista dos Tribunais, n. 735, São Paulo, 1997.

. "Responsabilidade pré-contratual no Código de Defesa do Consumidor: estudo comparativo com a responsabilidade pré-contratual no direito dos contratos". In: Revista do Direito do Consumidor, Volume 18, São Paulo, abril/1996.

KONDER, Carlos Nelson. Contratos Conexos: grupo de contratos, redes contratuais e contratos coligados. Rio de Janeiro: Renovar, 2006.

KPMG. Fusões e Aquisições. $1^{\circ}$ trimestre de 2016. Disponível em: < https://assets.kpmg.com/content/dam/kpmg/pdf/2016/05/fusoes-aquisicoes1trim-2016.pdf>. Acesso em 5.12.2016.

LAKE, Ralph B.; DRAETTA, Ugo. Letters of Intent and Other Precontractual Documents. $2^{\text {a }}$ ed., New Hampshire: Butterworths, 1994.

LARENZ, Karl. Base Del Negocio Jurídico e Cumplimiento de los Contratos. Tradução de Carlos Fernàndez Rodrìguez. Granada, Espanha: Comares, 2002.

- Metodologia da ciência do direito. Coimbra: Fundação Calouste Gulbenkian, 2005.

LEÃES, Luiz Gastão Paes de Barros. Protocolo de intenções sem força obrigatória. In: Pareceres. Volume I, São Paulo: Ed. Singular, 2004.

LEITÃO, Luís Manuel Teles de Menezes. "Negociações e responsabilidade précontratual nos contratos comerciais internacionais". Revista da Ordem dos Advogados, ano 60, Lisboa: janeiro de 2000 
LOPEZ, Teresa Ancona. Princípios Contratuais. In: Fundamentos e Princípios dos Contratos Empresariais, Coord. FERNANDES, Wanderley. $2^{a}$ ed., São Paulo: Saraiva, 2010.

LOTUFO, Renan; NANNI, Giovanni Ettore (coord.). Teoria geral dos contratos. São Paulo: Ed. Atlas, 2011.

MARINO, Francisco de Crescenzo. Interpretação do negócio jurídico. São Paulo: Ed. Saraiva, 2011.

MARQUEZ DE AVELAR, Letícia. A cláusula de não indenizar: uma releitura do instituto à luz do atual código civil brasileiro. Dissertação de mestrado defendida na Faculdade de Direito da Universidade de São Paulo. São Paulo: 2011.

MARTINS-COSTA, Judith. A boa-fé no direito privado: critérios para a sua aplicação. São Paulo: Ed. Marcial Pons, 2015.

- As cartas de intenção no processo formativo da contratação internacional: os graus de eficácia dos contratos e a responsabilidade prénegocial. Trabalho apresentado no seminário sobre "Contratos Internacionais e o MERCOSUL”, Faculdade de Direito, Universidade Federal do Rio Grande do Sul.

. "Contratos: conceito e evolução". In: LOTUFO, Renan; NANNI, Giovanni Ettore (coord.). Teoria geral dos contratos. São Paulo: Ed. Atlas, 2011.

. "Contratos Internacionais - cartas de intenção no processo formativo da contratação internacional - graus de eficácia dos contratos - responsabilidade pré-negocial”. In: Revista Trimestral de Direito Público, Volume 5, São Paulo: Malheiros, 1994.

MAXIMILIANO, Carlos. Hermenêutica e Aplicação do Direito. $19^{a}$ ed., Rio de Janeiro: Ed. Forense, 2005.

MESSINEO, Francesco. II Contratto in Genere. Tomo I, ristampa emendata. Milano: Giuffrè, 1973.

MILLER JR., Edwin L. Mergers and Acquistions: a step-by-step legal and practical guide. New Jersey: John Wiley \& Sons Inc., 2008.

MIRANDA, Custodio da Piedade Ubaldino. Comentários ao código civil: dos contratos em geral (arts. 421 a 480). São Paulo: Ed. Saraiva, 2013.

Model Stock Purchase Agreement, Second Edition, ABA Book Publishing, 2010. 
MONTEIRO, António Pinto. Cláusulas limitativas e de exclusão de responsabilidade civil. Coimbra: Ed. Almedina, 2003.

MOREIRA DA SILVA, Eva Sónia. Da responsabilidade pré-contratual por vinculação do dever de informação. Coimbra: Ed. Almedina, 2003.

MUNHOZ, Eduardo Secchi. Aquisição de Controle na Sociedade Anônima. São Paulo: Ed. Saraiva, 2013.

MUNIZ, Ian. Fusões e Aquisições: Aspectos Fiscais e Societários. $2^{a}$ ed., São Paulo: Quartier Latin, 2011.

NANNI, Giovanni Ettore. Direito Civil e Arbitragem. São Paulo: Ed. Atlas, 2014. . "A evolução do direito obrigacional: a concepção do direito civil constitucional e a transição da autonomia da vontade para a autonomia privada". In: LOTUFO, Renan (coord.). Cadernos de Direito Civil Constitucional. Caderno 2, Curitiba: Ed. Juará, 2001.

NEVES, Karina Penna. Deveres de consideração nas fases externas do contrato: responsabilidade pré e pós-contratual. $1^{\text {a }}$ ed., São Paulo: Ed. Almedina, 2015.

OESTERLE, Dale A. Mergers and Acquisitions in a Nutshell. St. Paul: Thomson/West, 2006.

PEDREIRA, José Luiz Bulhões; LAMY FILHO, Alfredo. Direito das Companhias, Volume II. Rio de Janeiro: Ed. Forense, 2009.

PEREIRA, Caio Mário da Silva. Responsabilidade civil. Rio de Janeiro: Ed. Forense, 1994.

PEREIRA, Regis Fichtner. A responsabilidade civil pré-contratual: teoria geral e responsabilidade pela ruptura das negociações contratuais. Rio de Janeiro: Ed. Renovar, 2001.

PETEFFI DA SILVA, Rafael. Responsabilidade Civil pela Perda de uma Chance. São Paulo: Ed. Atlas, 2007.

PINTO, Carlos Alberto da Mota. Responsabilidade pré-negocial pela não conclusão dos contratos. Coimbra, 1966.

PONTES DE MIRANDA, Francisco Cavalcanti. Tratado de direito privado. $4^{\mathrm{a}}$ edição, São Paulo: Ed. Revista dos Tribunais, tomo II, 1984.

. Tratado de direito privado. $4^{a}$ edição, São Paulo: Ed. Revista dos Tribunais 1983, t. IV, p. 91.

POPP, Carlyle. Responsabilidade civil pré-negocial: rompimento das tratativas. Curitiba: Ed. Juruá, 2004. 
. Responsabilidade civil pré-negocial: rompimento das tratativas. Curitiba: Ed. Juruá, 2001.

POSNER, Richard A. Law and Economics of Contract Interpretation. Texas Law Review, 2004.

POTHIER. Tratado das Obrigações Pessoais e Recíprocas. Tomo I, Rio de Janeiro: editora e ano desconhecidos, tradutor - José Homem Correa Telles.

PRATA, Ana. Cláusulas de Exclusão e Limitação de Responsabilidade Contratual. Coimbra: Almedina, 1985.

. Notas sobre a responsabilidade pré-contratual. Coimbra: Ed. Almedina, 2005.

O Contrato Promessa e o seu Regime Civil. Coimbra: Almedina, 2001.

PRICEWATERHOUSECOOPERS. Fusões e Aquisições no Brasil. Dezembro de 2015. Disponível

em: $<$ https://www.pwc.com.br/pt/publicacoes/servicos/assets/fusoesaquisicoes/2015/pwc-fusoes-aquisicoes-dezembro-15.pdf>. Acesso em: 27 de julho de 2016.

RAÓ, Vicente. Ato Jurídico. $4^{\mathrm{a}}$ edição, São Paulo: Revista dos Tribunais, 1997.

REBELO, Nikolai Sosa. Os Deveres Fiduciários dos Administradores de S.A. em Operações de Fusões e Aquisições. Porto Alegre: Livraria do Advogados, 2015.

REED, Stanley Foster et al. The Art of M\&A - Mergers and Acquisitions Buyout Guide. New York: McGraw-Hill, 2007.

RIDOLFO NETO, Arthur. "Introdução às operações de fusões, aquisições e reestruturação societária. Métodos mais utilizados para precificação de empresas". In: RIOS DA ROCHA, Dinir Salvador; QUATTRINI, Larissa Teixeira (coord.). Fusões, aquisições, reorganizações societárias e due diligence. São Paulo: Ed. Saraiva, 2014.

RIOS DA ROCHA, Dinir Salvador; QUATTRINI, Larissa Teixeira (coord.). Fusões, aquisições, reorganizações societárias e due diligence. São Paulo: Ed. Saraiva, 2014.

. NUNES, Marcelo Galiciano. "Term sheet e contrato de compra e venda de ações ou quotas". In: RIOS DA ROCHA, Dinir Salvador; QUATTRINI, Larissa Teixeira (coord.). Fusões, aquisições, reorganizações societárias e due diligence. São Paulo: Ed. Saraiva, 2014. 
ROPPO, Enzo. O contrato. Coimbra: Ed. Almedina, 2009

SADDI, Jairo (org.). Fusões e Aquisições: Aspectos Jurídicos e Econômicos. São Paulo: IOB, 2002.

SALANIÉ, Bernard. The Economics of Contracts. $2^{\mathrm{a}}$ ed., Cambridge (Massachusetts): The MIT Press, 2005.

SALLES, Roberto; FREITAS, Bernardo Vianna; ALVES, Juliana Fonseca. "Combinações de Negócios, IFRS e Regime Contábil-Fiscal Pós-Lei $N^{\circ}$. 12.973 - Impactos nas Finanças Corporativas". In: BOTREL, Sérgio; BARBOSA, Henrique. Finanças Corporativas: aspectos jurídicos e estratégicos. São Paulo: Atlas, 2016.

SAVI, Sérgio. Responsabilidade Civil por Perda de uma Chance. São Paulo: Ed. Atlas, 2006.

SILVA, Jorge Cesa Ferreira. A boa-fé e a violação positiva do contrato. Rio de Janeiro: Ed. Renovar, 2002.

SZTAJN, Rachel. "Reorganização societária e concorrência". In: WARDE JR, Walfrido Jorge (coord.). Fusão, cisão, incorporação e temas correlatos. São Paulo: Quartier Latin, 2009.

TALAMINI, Eduardo. "Um processo para chamar de seu: nota sobre os negócios jurídicos processuais". Disponível em: http://www.justen.com.br/pdfs/IE104/Eduardo-um\%20processo-pra-

chamar.pdf. Acesso em: 3 de janeiro de 2017.

TAMBURRINO, Giuseppe. Vincoli Unilaterali nella Formazione Progressiva Del Contratto. Milano: Giuffrè Editore, 1954.

THOMPSON JR., Samuel C. Business Planning for Mergers and Acquisitions. $3^{\text {a }}$ ed. Carolina Academics Press, 2008.

TOMASETTI JUNIOR, Alcides. Execução do Contrato Preliminar. Doutorado em direito civil pela Faculdade de Direito da Universidade de São Paulo, 1982.

TOMASEVICIUS FILHO, Eduardo. Informação Assimétrica, Custos de Transação, Princípios da Boa-Fé. Tese de Doutorado em Direito Civil defendida na Faculdade de Direito da Universidade de São Paulo. São Paulo, 2007.

UGOLINI, Sonia. "Gentlemen's Agreement sono Giuridicamente Vincolante?" In: Rivista Contratto e Impresa. Milano: CEDAM, 2001.

VENOSA, Sílvio de Salvo. Direito Civil - Parte Geral. $7^{\text {a }}$ ed., São Paulo: Ed. Atlas, 2007. 
Direito Civil - Teoria Geral das Obrigações e Teoria Geral dos Contratos. $8^{a}$ ed., São Paulo: Ed. Atlas, 2008.

WALD, Arnoldo; RANGEL DE MORAES, Luiz; e WAISBERG, Ivo. "Fusões, incorporações e aquisições - Aspectos societários, contratuais e regulatórios". In: Fusão, cisão, incorporação e temas correlatos. WARDE JÚNIOR, Walfrido Jorge (coord). São Paulo: Ed. Quartier latin, 2009, p 53.

WERHANE, Patrícia H. Two Ethical Issues in Mergers and Acquisitions. Disponível em <http://link.springer.com/article/10.1007/BF00381996>. Acesso em: 26 de dezembro de 2016.

WHALLEY, Michael e SEMLER, Franz-Jörg. International Business Acquisitions: Major Legal Issues and Due Diligence. $3^{\mathrm{a}}$ ed. Kluwer Law International, 2007.

WOLFF, Norris D. Letters of intent, preliminary agreements, and binding acquisition agreements. Banking Law Journal 292, 1994.

YARSHELL, Flávio Luiz. Tutela Jurisdicional Específica nas Obrigações de Prestar Declaração de Vontade. Tese de Mestrado defendida junto ao Departamento de Direito Processual da Universidade de São Paulo.

ZANETTI, Cristiano de Sousa. A Conservação dos Contratos Nulos por Defeito de Forma. São Paulo: Ed. Quartier Latin, 2013. . Responsabilidade pela Ruptura das Negociações. São Paulo: Ed. Juarez de Oliveira, 2005. 